\title{
MICRO FINANCING SCHEMES \& THEIR IMPACT ON POVERTY REDUCTION - A STUDY CONDUCTED ON MEMBERS OF SELF HELP GROUPS IN PUNJAB (INDIA)
}

Tejbir Kaur ${ }^{*}$, Rajdeep Singh ${ }^{2}$

1*,2 Assistant Professor, School of Commerce \& Management,Sri Guru Granth Sahib World University, Fatehgarh Sahib

*Correspondence Author: kaurtejbir@gmail.com

\begin{abstract}
:
In a country like India where faster, sustainable and inclusive growth is the objective/mission of the government, there arises a need to study the impact of microfinance through SHG's (Self Help Groups) on poverty reduction. The current study examines to what extent microfinance through SHG's has helped the members in raising their economic status. The target population for the study was the members of SHG's at district Fatehgarh Sahib. A sample of 100 members out of the universe was selected using convenience sampling and a survey was conducted. The reliability of data was confirmed by using cronbach's reliability test. Descriptive statistics and cross tabulation have been used to analyze the data. The study shows a positive impact of micro financing Schemes on poverty reduction.
\end{abstract}

Keywords:

SHG's, Poverty, Micro-Finance.

\section{INTRODUCTION}

Microfinance is a tool or provision to provide different types of financial products and services to the low-income clients depending upon their needs. The concept of microfinance is of ancient origin in India. Traditionally money lenders have provided microcredit to the poor people and charged exorbitant rates of interest. This led to the exploitation of borrowers which resulted into a vicious circle of debt trap for them.

But in today's time the concept of microfinance in India does not involves these exploitative practices. In fact it refers to the provision of microfinance products and services to the poor at nominal and reasonable rates of interest and is aimed at the welfare of the people without endangering the sustainability of the organization or institution providing such products and services. According to CGAP, "microfinance can be defined as supply of loans, savings and other basic financial services to the poor." In the International Year of Microcredit 2005, "Microfinance was referred to as loans, savings, insurance, transfer services and other financial products targeted at low-income clients." 


\section{INTERNATIONAL JOURNAL of RESEARCH -GRANTHAALAYAH \\ A knowledge Repository}

Management

Different microfinance products and services provided in India are given in the table below.

\begin{tabular}{|l|l|}
\hline 1.1.MICROFINANCE PRODUCTS AND SERVICES \\
\hline MICROFINANCE PRODUCTS & MICROFINANCE SERVICES \\
\hline Microcredit & Financial Intermediations \\
\hline Micro-savings & Social Intermediations \\
\hline Micro-insurance & Business Development Services \\
\hline Pension and Provident fund & Social Services \\
\hline Payment Transfers & \\
\hline
\end{tabular}

\subsection{SELF HELP GROUPS}

Self Help Groups comprise of about 10-20 people who come together to resolve various socioeconomic problems being faced by them. The members of SHG's are homogeneous maybe in terms of caste, gender, religion, income level, etc. They join hands together to resolve their common problems and issues. The self-help groups work on peer pressure which eliminates the need for any collateral as a security for availing any loan. It is based on four important premises, i.e. (i) Self-help is the best help (ii) Unity is the strength (iii) United will stand and divided will fall (iv) We can make our own Bank.

According to Reserve Bank of India, "A self-help group is a registered or unregistered group of micro entrepreneurs having homogeneous social and economic background voluntarily, coming together to save small amounts regularly to mutually agree to contribute to a common fund and to meet their emergency needs on mutual help basis. The group members use collective and wisdom pressure to ensure proper end use of credit and timely repayment thereof. In fact, peer pressure has been recognized as an effective substitute for collaterals."

\section{REVIEW OF LITERATURE}

Mohapatra (2012) SHG contributed to socioeconomic empowerment of women at household level.The component of empowerment of women are access to economic resources, participation in economic decision making, opportunities for self-development, participation in socio-political decision making, scope for skill development and impact on general welfare of the family and community.

Surender, Kumari, and Sehrawat (2011) there is a positive impact of SHGs on employment generation. Number of working days of beneficiaries in Live- Stock, business and any other profession have increased. In this way, it has increased employment which led to more income and more savings. Rajendran and Raya (2011) conclude that growth of SHGs are essential for the member as they ensure better standards of living and thereby the individual; family and social empowerment. There is a high level of political empowerment as compared to economic empowerment and poor level of social empowerment. 


\section{INTERNATIONAL JOURNAL of RESEARCH -GRANTHAALAYAH \\ A knowledge Repository}

Management

Subramaniam (2010) concluded that microfinance is a powerful for poverty alleviation and development. In order to declare microfinance success in India, not only do tens of millions of more people need to be reached but those services must have a transformational impact on their lives and those of their family members. SHGs have ushered a silent revolution of poverty alleviation and women empowerment. Pillai and Nadarajan (2010) the study concludes that microfinance has brought better psychological and social empowerment than economic empowerment. SHGs are essential for the member as they ensure better standards of living and thereby the individual,family and social empowerment. Banerjee (2009) it was observed that from low-income group more people have shifted to high-income levels. This has reduced the inequality in the distribution of family monthly income. Apart from the scorching pace of growth, the rapid spread of microfinance (MF) has provided competition, to rural moneylenders. Raghavan (2009) by participating in various income generating -cum-developmental activities, the morale and confidence of women became very high. Capacity of the poor women of the State in several areas has gone up considerably. Status of women in families and community has also improved. Nirmala and Geetha (2009) highlight positive impact of microfinance. It contributes for improvement in household economic welfare and enterprise stability or growth.

Singh, Kaushal and Gautam (2007) Group process had a positive significant relationship. Participation in Self Help Groups enabled them to gain self-confidence, social and economic empowerment and capacity building. Moyle, Dollard and Biswas (2006) SHGs achieved both economic and personal empowerment in terms of collective efficiency, pro-active attitudes, selfesteem and self-efficacy.

\section{METHODOLOGY}

\subsection{OBJECTIVES OF THE STUDY}

1. To check whether there is any impact of micro financing schemes on poverty reduction.

2. To check the perceptions of the members of SHG's about Micro Financing Schemes.

\subsection{SCOPE OF THE STUDY}

The study evaluates the impact of micro financing schemes on poverty reduction at district Fatehgarh Sahib, Punjab, India. The respondents were the members of the SHG's at district Fatehgarh Sahib, Punjab, India. The study focused on exploring how SHGs increase their income and savings to reduce poverty. The study examines how far the bank finance through Self-Help Groups has helped the members in raising their economic status in terms of expenditure on household consumer durables, annual consumption expenditure, assets generation, annual household income, annual savings and man-days employment. 


\section{INTERNATIONAL JOURNAL of RESEARCH -GRANTHAALAYAH \\ A knowledge Repository}

Management

\subsection{RESEARCH DESIGN}

The present study is exploratory in nature and has been carried out at district Fatehgarh Sahib (Punjab). The objective of exploratory study is to provide insights and understanding about something and sample size is usually small (Malhotra, 2004).

\subsection{SAMPLING DESIGN}

The target population comprised of the member of SHG's at district Fatehgarh Sahib (Punjab). A sample of 100 respondents have been selected, all of whom are the members of one or more SHG's at district Fatehgarh Sahib (Punjab). The sample has been selected on the basis of nonprobability convenience sampling.

\subsection{DATA COLLECTION STRATEGY}

\subsubsection{TYPE OF DATA}

Both primary and secondary data has been used in this study.

Primary data collection: The primary data collection method explored the originality of data through gathering information relevant to the study. Primary data was obtained from members of SHGs at district Fatehgarh sahib. By use of the questionnaires and interview manuals, the research gathered data from the members of SHGs which in fact were the primary concern of this survey design approach.

Secondary data collection: Secondary data collection explored methods supplementary to the above method where data was obtained from text books, the internet and other materials (such as journals, newspapers, etc.) as found useful to the study. This kind of data collection method was also important to the study especially in the literature review.

\subsubsection{DATA COLLECTION TOOL}

Major data for proposed study has been collected by means of structured questionnaire. To meet this condition a 'Likert scale' of five points ranging from 1 (Strongly Agree) to 5 ( Strongly Disagree) has been used as a survey instrument to record impact of micro financing schemes on poverty reduction for self-help groups.

\section{ANALYSIS AND INTERPRETATION}

\subsection{RELIABILITY}

To check the reliability of data the reliability test has been applied.

\section{Perceptions of the members on the impact of SHGs}




\section{INTERNATIONAL JOURNAL of RESEARCH -GRANTHAALAYAH \\ A knowledge Repository}

\section{Reliability Statistics}

\begin{tabular}{|r|r|}
\hline Cronbach's Alpha & N of Items \\
\hline .639 & \\
\hline
\end{tabular}

Table1-: Item-Total Statistics

\begin{tabular}{|c|c|c|c|c|}
\hline & \begin{tabular}{|l|} 
Scale Mean if \\
Item Deleted
\end{tabular} & \begin{tabular}{|l|} 
Scale \\
Variance if \\
Item Deleted
\end{tabular} & $\begin{array}{l}\text { Corrected } \\
\text { Item-Total } \\
\text { Correlation }\end{array}$ & \begin{tabular}{|l|} 
Cronbach's \\
Alpha if Item \\
Deleted
\end{tabular} \\
\hline $\begin{array}{l}\text { Membership in SHG increases } \\
\text { capacity to spend more }\end{array}$ & 18.5600 & 8.714 & .023 & .565 \\
\hline $\begin{array}{l}\text { Membership in SHG increases } \\
\text { the savings. }\end{array}$ & 18.5900 & 8.446 & .109 & .540 \\
\hline $\begin{array}{l}\text { Membership in self-help group } \\
\text { improves } \\
\text { independence }\end{array}$ & 43.7300 & 23.492 & .432 & .647 \\
\hline $\begin{array}{l}\text { Membership in self-help group } \\
\text { improves the standard of living. }\end{array}$ & 43.7200 & 24.709 & .272 & .666 \\
\hline $\begin{array}{l}\text { Membership in self-help group } \\
\text { generates employment }\end{array}$ & 44.0900 & 27.759 & -.164 & .703 \\
\hline $\begin{array}{l}\text { Membership in self-help group } \\
\text { eradicates poverty. }\end{array}$ & 41.5800 & 26.246 & .038 & .692 \\
\hline $\begin{array}{l}\text { Membership in self-help group } \\
\text { facilitates greater access to } \\
\text { financial resources outside the } \\
\text { household. }\end{array}$ & 42.3200 & 23.594 & .313 & .661 \\
\hline
\end{tabular}

\section{INTERPRETATION}

The reliability of this data was ensured through Cronbach's Alpha value that is 0.679 . As the alpha value is closer to 1 then it represent that data is reliable. 


\section{INTERNATIONAL JOURNAL of RESEARCH -GRANTHAALAYAH \\ A knowledge Repository}

\subsection{BACKGROUND INFORMATION}

\section{DEMOGRAPHIC PROFILE OF THE RESPONDENTS}

TABLE 2

\begin{tabular}{|l|l|l|l|l|}
\hline Demographics & Frequency & Percent & $\begin{array}{l}\text { Cumulative } \\
\text { Percent }\end{array}$ \\
\hline Age in Years & $20-25$ & 13 & $13.0 \%$ & 13.0 \\
& $25-30$ & 22 & $22.0 \%$ & 35.0 \\
& $30-35$ & 18 & $18.0 \%$ & 53.0 \\
& $35-40$ & 21 & $21.0 \%$ & 74.0 \\
& $40-45$ & 9 & $9.0 \%$ & 83.0 \\
& More than 45 & 17 & $17.0 \%$ & 100.0 \\
\cline { 2 - 5 } & Total & 100 & $100.0 \%$ & \\
\hline \multirow{5}{*}{ Occupation } & Service & 26 & $26.0 \%$ & 26.0 \\
& Business & 5 & $5.0 \%$ & 31.0 \\
& Self-Employed & 21 & $21.0 \%$ & 52.0 \\
& Unemployed & 46 & $46.0 \%$ & 98.0 \\
& Student & 2 & $2.0 \%$ & 100.0 \\
\cline { 2 - 5 } & Total & 100 & $100.0 \%$ & \\
\hline \multirow{5}{*}{ Qualification } & Upto Matric & 31 & $31.0 \%$ & 31.0 \\
& Upto +2 & 29 & $29.0 \%$ & 60.0 \\
& Bachelors & 11 & $11.0 \%$ & 71.0 \\
& Others & 29 & $29.0 \%$ & 100.0 \\
\cline { 2 - 5 } & Total & 100 & $100.0 \%$ & \\
\hline Monthly & Not Earning & 51 & $51.0 \%$ & 51.0 \\
Income & $<10,000$ & 39 & $39.0 \%$ & 90.0 \\
(in Rs.) & $10,001-20,000$ & 10 & $10.0 \%$ & 100.0 \\
\cline { 2 - 5 } & Total & 100 & $100.0 \%$ & \\
\hline
\end{tabular}

\subsection{PERCEPTIONS OF THE MEMBERS ON THE IMPACT OF SHGS}

\section{Membership in SHG increases capacity to spend more}

Table 3

\begin{tabular}{|l|r|r|r|r|}
\hline & Frequency & Percent & \multicolumn{1}{|c|}{$\begin{array}{c}\text { Valid } \\
\text { Percent }\end{array}$} & $\begin{array}{c}\text { Cumulative } \\
\text { Percent }\end{array}$ \\
\hline Strongly agree & 25 & 25.0 & 25.0 & 25.0 \\
Agree & 45 & 45.0 & 45.0 & 70.0
\end{tabular}




\section{INTERNATIONAL JOURNAL of RESEARCH -GRANTHAALAYAH A knowledge Repository}

\begin{tabular}{|l|r|r|r|r|}
\hline Neutral & 16 & 16.0 & 16.0 & 86.0 \\
Disagree & 7 & 7.0 & 7.0 & 93.0 \\
Strongly & 7 & 7.0 & 7.0 & 100.0 \\
disagree & 100 & 100.0 & 100.0 & \\
Total & & & \\
\hline
\end{tabular}

2. Membership in SHG increases the value of assets

Table no 4

\begin{tabular}{|l|l|l|l|l|}
\hline & Frequency & Percent & $\begin{array}{l}\text { Valid } \\
\text { Percent }\end{array}$ & $\begin{array}{l}\text { Cumulative } \\
\text { Percent }\end{array}$ \\
\hline Strongly agree & 12.0 & 12.0 & 12.0 & 12.0 \\
Agree & 42.0 & 42.0 & 42.0 & 54.0 \\
Neutral & 36.0 & 36.0 & 36.0 & 90.0 \\
Disagree & 5.0 & 5.0 & 5.0 & 95.0 \\
Strongly & 5.0 & 5.0 & 5.0 & 100.0 \\
disagree & 100 & 100.0 & 100.0 & \\
\hline Total & & & \\
\hline
\end{tabular}

3. Membership in SHG increases the income

Table 5

\begin{tabular}{|l|r|r|r|r|}
\hline & Frequency & Percent & $\begin{array}{c}\text { Valid } \\
\text { Percent }\end{array}$ & $\begin{array}{c}\text { Cumulative } \\
\text { Percent }\end{array}$ \\
\hline Strongly agree & 33 & 33.0 & 33.0 & 33.0 \\
Agree & 48 & 48.0 & 48.0 & 81.0 \\
Neutral & 14 & 14.0 & 14.0 & 95.0 \\
Disagree & 3 & 3.0 & 3.0 & 98.0 \\
Strongly & 2 & 2.0 & 2.0 & 100.0 \\
disagree & 100 & 100.0 & 100.0 & \\
Total & & \\
\hline
\end{tabular}




\section{INTERNATIONAL JOURNAL of RESEARCH -GRANTHAALAYAH

4. Membership in SHG increases the savings

Table 6

\begin{tabular}{|l|r|r|r|r|}
\hline & Frequency & Percent & Valid Percent & $\begin{array}{c}\text { Cumulative } \\
\text { Percent }\end{array}$ \\
\hline Strongly & 30 & 30.0 & 30.0 & 30.0 \\
agree & 56 & 56.0 & 56.0 & 86.0 \\
Agree & 12 & 12.0 & 12.0 & 98.0 \\
Neutral & 1 & 1.0 & 1.0 & 99.0 \\
Disagree & 1 & 1.0 & 1.0 & 100.0 \\
Strongly & 100 & 100.0 & 100.0 & \\
disagree & & & \\
Total & & & \\
\hline
\end{tabular}

4.3.STATE YOUR ACCEPTANCE LEVEL ON THE FOLLOWING WITH RESPECT SELFHELP GROUPS.

1) Membership in self-help group improves economic independence.

Table 7

\begin{tabular}{|l|l|l|l|l|}
\hline & Frequency & Percent & $\begin{array}{l}\text { Valid } \\
\text { Percent }\end{array}$ & $\begin{array}{l}\text { Cumulative } \\
\text { Percent }\end{array}$ \\
\hline Strongly agree & 41 & 41.0 & 41.0 & 41.0 \\
Agree & 39 & 39.0 & 39.0 & 80.0 \\
Neutral & 17 & 17.0 & 17.0 & 97.0 \\
Disagree & 2 & 2.0 & 2.0 & 99.0 \\
$\begin{array}{l}\text { Strongly } \\
\text { disagree }\end{array}$ & 1 & 1.0 & 1.0 & 100.0 \\
Total & 100 & 100.0 & 100.0 & \\
\hline
\end{tabular}

2) Membership in self-help group improves the standard of living.

Table 8

\begin{tabular}{|l|l|l|l|l|}
\hline & Frequency & Percent & $\begin{array}{l}\text { Valid } \\
\text { Percent }\end{array}$ & $\begin{array}{l}\text { Cumulative } \\
\text { Percent }\end{array}$ \\
\hline Strongly agree & 37 & 37.0 & 37.0 & 37.0
\end{tabular}




\section{INTERNATIONAL JOURNAL of RESEARCH -GRANTHAALAYAH A knowledge Repository}

\begin{tabular}{|l|l|l|l|l|}
\hline Agree & 45 & 45.0 & 45.0 & 82.0 \\
Neutral & 15 & 15.0 & 15.0 & 97.0 \\
Disagree & 2 & 2.0 & 2.0 & 99.0 \\
$\begin{array}{l}\text { Strongly } \\
\text { disagree }\end{array}$ & 1 & 1.0 & 1.0 & 100.0 \\
Total & 100 & 100.0 & 100.0 & \\
\hline
\end{tabular}

\section{3) Membership in self-help group generates employment}

Table 9

\begin{tabular}{|l|l|l|l|l|}
\hline & Frequency & Percent & $\begin{array}{l}\text { Valid } \\
\text { Percent }\end{array}$ & $\begin{array}{l}\text { Cumulative } \\
\text { Percent }\end{array}$ \\
\hline Strongly agree & 64 & 64.0 & 64.0 & 64.0 \\
Agree & 28 & 28.0 & 28.0 & 92.0 \\
Neutral & 2 & 2.0 & 2.0 & 94.0 \\
Disagree & 3 & 3.0 & 3.0 & 97.0 \\
$\begin{array}{l}\text { Strongly } \\
\text { disagree }\end{array}$ & 3 & 3.0 & 3.0 & 100.0 \\
Total & 100 & 100.0 & 100.0 & \\
\hline
\end{tabular}

4) Membership in self-help group eradicates poverty

Table 10

\begin{tabular}{|l|l|l|l|l|}
\hline & Frequency & Percent & $\begin{array}{l}\text { Valid } \\
\text { Percent }\end{array}$ & $\begin{array}{l}\text { Cumulative } \\
\text { Percent }\end{array}$ \\
\hline Strongly agree & 17 & 17 & 17 & 17 \\
Agree & 60 & 60 & 60 & 77 \\
Neutral & 19 & 19.0 & 19.0 & 96 \\
Disagree & 3 & 3 & 3 & 99 \\
$\begin{array}{l}\text { Strongly } \\
\text { disagree }\end{array}$ & 1 & 1 & 1 & 100.0 \\
Total & 100 & 100.0 & 100.0 & \\
\hline
\end{tabular}




\section{INTERNATIONAL JOURNAL of RESEARCH -GRANTHAALAYAH \\ A knowledge Repository}

\subsection{CROSS TABULATIONS}

A. Monthly income * Membership in SHG increases capacity to spend more Table 11

\begin{tabular}{|c|c|c|c|c|c|c|c|c|}
\hline & \multicolumn{5}{|c|}{$\begin{array}{l}\text { Membership in SHG increases capacity to } \\
\text { spend more }\end{array}$} & \multirow[b]{2}{*}{ Total } \\
\hline & & & $\begin{array}{l}\text { Strongly } \\
\text { agree }\end{array}$ & Agree & $\begin{array}{l}\text { No } \\
\text { objectio } \\
\text { n }\end{array}$ & Disagre & $\begin{array}{l}\text { Strongly } \\
\text { disagree }\end{array}$ & \\
\hline \multirow{6}{*}{$\begin{array}{l}\text { Monthly } \\
\text { income }\end{array}$} & & Count & 8 & 29 & 10 & 2 & 2 & 51 \\
\hline & ning & $\begin{array}{l}\% \text { within } \\
\text { Membership in SHG } \\
\text { increases capacity to } \\
\text { spend more }\end{array}$ & $32.0 \%$ & $\begin{array}{l}64.44 \\
\%\end{array}$ & $62.5 \%$ & 28.57 & $28.57 \%$ & $51.0 \%$ \\
\hline & $<10,000$ & Count & 14 & 14 & 4 & 3 & 4 & 39 \\
\hline & & $\begin{array}{l}\% \text { within } \\
\text { Membership in SHG } \\
\text { increases capacity to } \\
\text { spend more }\end{array}$ & $56.0 \%$ & $\begin{array}{l}31.11 \\
\%\end{array}$ & $25.00 \%$ & $42.86 \%$ & $57.14 \%$ & $39.0 \%$ \\
\hline & 10,001 & - Count & 3 & 2 & 2 & 2 & 1 & 10 \\
\hline & & $\begin{array}{l}\% \text { within } \\
\text { Membership in SHG } \\
\text { increases capacity to } \\
\text { spend more }\end{array}$ & $12.0 \%$ & $4.4 \%$ & $12.5 \%$ & $28.57 \%$ & $14.3 \%$ & $10.0 \%$ \\
\hline \multirow[t]{2}{*}{ Total } & & Count & 25 & 45 & 16 & 7 & 7 & 100 \\
\hline & & $\begin{array}{l}\% \text { within } \\
\text { Membership in SHG } \\
\text { increases capacity to } \\
\text { spend more }\end{array}$ & $100.0 \%$ & $\begin{array}{l}100.0 \\
\%\end{array}$ & $100.0 \%$ & $100.0 \%$ & $100.0 \%$ & $100.0 \%$ \\
\hline
\end{tabular}

B. Age * Membership in SHG increases the value of assets

Table 12

\begin{tabular}{|l|l|l|}
\hline Membership in SHG increases the value of assets & Total \\
\hline
\end{tabular}




\section{INTERNATIONAL JOURNAL of RESEARCH -GRANTHAALAYAH \\ A knowledge Repository}

\begin{tabular}{|c|c|c|c|c|c|c|c|}
\hline & & $\begin{array}{l}\text { Strongly } \\
\text { agree }\end{array}$ & Agree & $\begin{array}{c}\text { No } \\
\text { objection }\end{array}$ & Disagree & \begin{tabular}{|c} 
Strongl \\
$\mathrm{y}$ \\
disagre \\
$\mathrm{e}$
\end{tabular} & \\
\hline$e^{A g} \begin{array}{ll}\text { Ag } & 20-25 \\
\end{array}$ & $\begin{array}{l}\text { Count } \\
\% \text { within } \\
\text { Membership in } \\
\text { SHG increases } \\
\text { the value of } \\
\text { assets }\end{array}$ & 1 & $16.7 \%$ & $13.89 \%$ & $.0 \%$ & 0 & $13.0 \%$ \\
\hline $25-30$ & $\begin{array}{l}\text { Count } \\
\% \text { within } \\
\text { Membership in } \\
\text { SHG increases } \\
\text { the value of } \\
\text { assets }\end{array}$ & $16.7 \%$ & 13 & $13.89 \%$ & $20.0 \%$ & $20.0 \%$ & $22.0 \%$ \\
\hline $30-35$ & $\begin{array}{l}\text { Count } \\
\% \text { within } \\
\text { Membership in } \\
\text { SHG increases } \\
\text { the value of } \\
\text { assets }\end{array}$ & $16.7 \%$ & $21.42 \%$ & $13.89 \%$ & $20.0 \%$ & $20.0 \%$ & $18.0 \%$ \\
\hline $35-40$ & $\begin{array}{l}\text { Count } \\
\% \text { within } \\
\text { Membership in } \\
\text { SHG increases } \\
\text { the value of } \\
\text { assets }\end{array}$ & $25.0 \%$ & $23.81 \%$ & $16.67 \%$ & $20.0 \%$ & $20.0 \%$ & $21.0 \%$ \\
\hline $40-45$ & $\begin{array}{l}\text { Count } \\
\% \text { within } \\
\text { Membership in } \\
\text { SHG increases } \\
\text { the value of } \\
\text { assets }\end{array}$ & $16.7 \%$ & $2.4 \%$ & $11.11 \%$ & $20.0 \%$ & $20.0 \%$ & $9.0 \%$ \\
\hline$>45$ & Count & 2 & 2 & 11 & 1 & 1 & 17 \\
\hline
\end{tabular}




\section{INTERNATIONAL JOURNAL of RESEARCH -GRANTHAALAYAH \\ A knowledge Repository}

\begin{tabular}{|c|c|c|c|c|c|c|c|}
\hline & $\begin{array}{l}\% \text { within } \\
\text { Membership in } \\
\text { SHG increases } \\
\text { the value of } \\
\text { assets }\end{array}$ & $16.7 \%$ & $4.8 \%$ & $30.6 \%$ & $20.0 \%$ & $20.0 \%$ & $17.0 \%$ \\
\hline Total & $\begin{array}{l}\text { Count } \\
\% \text { within } \\
\text { Membership in } \\
\text { SHG increases } \\
\text { the value of } \\
\text { assets }\end{array}$ & 12 & 42 & 36 & 5 & $100.0 \%$ & $100.0 \%$ \\
\hline
\end{tabular}

C. Age * Membership in SHG increases the income

Table 13

\begin{tabular}{|c|c|c|c|c|c|c|c|}
\hline & \multicolumn{5}{|c|}{ Membership in SHG increases the income } & \multirow[b]{2}{*}{ Total } \\
\hline & & $\begin{array}{c}\text { Strongly } \\
\text { agree }\end{array}$ & Agree & $\begin{array}{c}\text { No } \\
\text { objection }\end{array}$ & $\begin{array}{c}\text { Disagre } \\
\mathrm{e}\end{array}$ & $\begin{array}{l}\text { Strongly } \\
\text { disagree }\end{array}$ & \\
\hline \multicolumn{2}{|c|}{$\begin{array}{l}\text { Age 20-25 Count } \\
\qquad \begin{array}{l}\% \text { within } \\
\text { Membership in } \\
\text { SHG increases the } \\
\text { income }\end{array}\end{array}$} & $21.21 \%$ & $6.25 \%$ & $21.42 \%$ & $.0 \%$ & $.0 \%$ & $13.0 \%$ \\
\hline & $\begin{array}{l}\text { 25-30 Count } \\
\text { \% within } \\
\text { Membership in } \\
\text { SHG increases the } \\
\text { income }\end{array}$ & $33.33 \%$ & $12.5 \%$ & $35.71 \%$ & $.0 \%$ & $.0 \%$ & $22.0 \%$ \\
\hline & $\begin{array}{l}\text { 30-35 Count } \\
\text { \% within } \\
\text { Membership in } \\
\text { SHG increases the } \\
\text { income }\end{array}$ & $18.2 \%$ & $18.75 \%$ & $21.43 \%$ & $.0 \%$ & $.0 \%$ & $18.0 \%$ \\
\hline & 35-40 Count & 6 & 13 & 2 & 0 & 0 & \\
\hline
\end{tabular}




\section{INTERNATIONAL JOURNAL of RESEARCH -GRANTHAALAYAH \\ A knowledge Repository

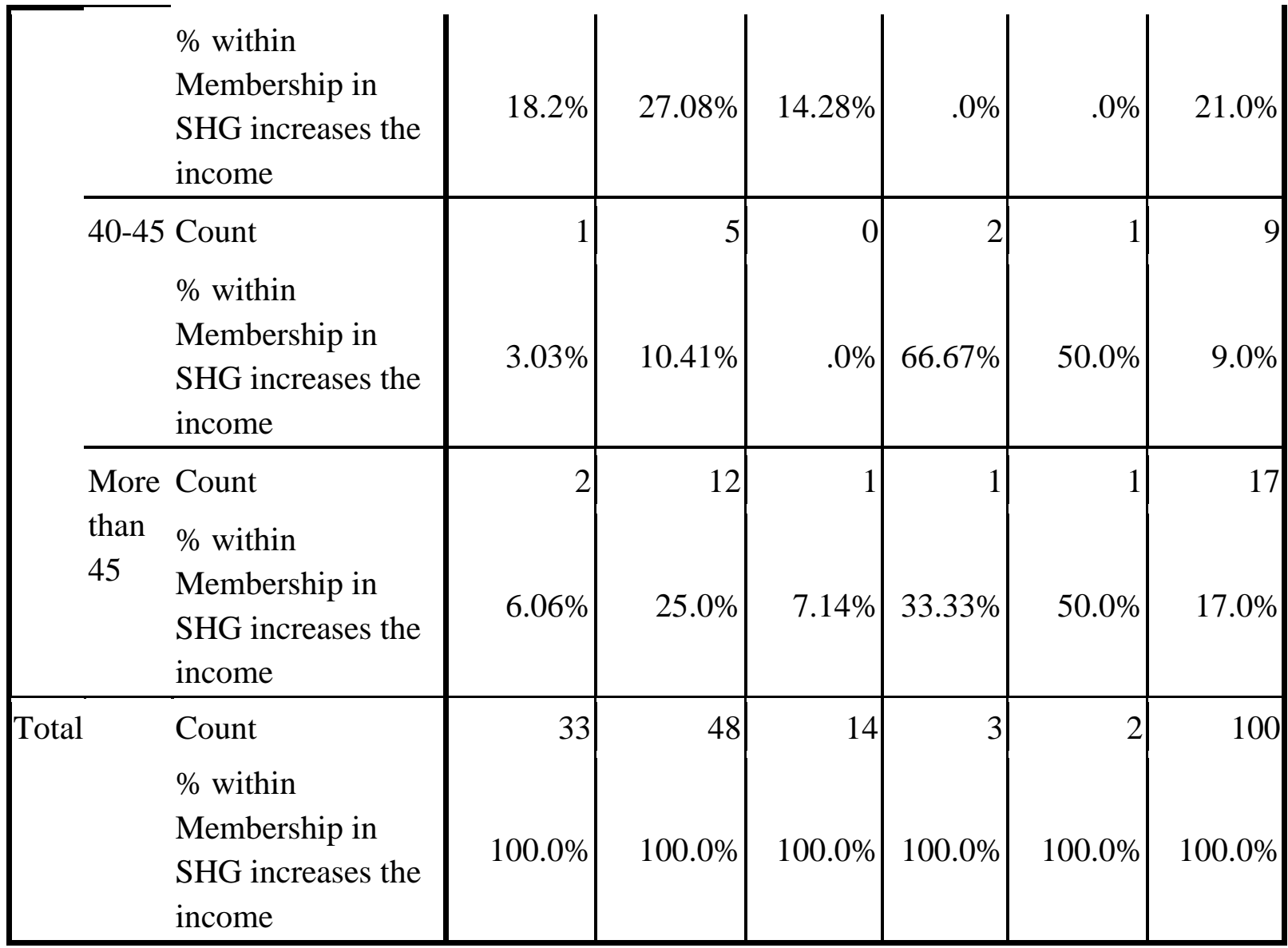

\begin{tabular}{|c|c|c|c|c|c|c|}
\hline $\begin{array}{l}\text { \% within Membership } \\
\text { in self-help group } \\
\text { generates employment }\end{array}$ & $100.0 \%$ & $100.0 \%$ & $100.0 \%$ & $100.0 \%$ & $100.0 \%$ & $100.0 \%$ \\
\hline
\end{tabular}

\section{FINDINGS \& DISCUSSION}

\subsection{MAJOR FINDINGS OF THE STUDY}

The study analyzed the socio-economic profile of the sample SHG members, economic activity management and perceptions of the sample respondents regarding impact of the SHGs. The major findings that emerge from the present study can be succinctly outlined as follows-:

$>$ There is a significant positive impact of microfinance through SHG on the member's capacity to spend more (Refer to table 3 ). Of all the respondents $70 \%$ respondents were of the opinion that membership in SHG increasees the capacity to spend more. $25 \%$ of the respondents strongly agreed to this while $45 \%$ of the respondents simply agreed to it. 


\section{INTERNATIONAL JOURNAL of RESEARCH -GRANTHAALAYAH \\ A knowledge Repository}

Management

$>$ About $57 \%$ of the respondents felt that membership in SHG leads to increase in value of the assets (Refer table 4). However, still 36\% of the respondents feel that it didn't have any impact on the value of the assets.

$>$ As regards the impact on income, $81 \%$ of the respondents supported the statement that membership in SHG has increased their income (Refer table 5). On the other hand only $5 \%$ of the respondents disagreed to this statement. Therefore, it strongly confirms the positive impact of microfinance through SHG on the income of the beneficaries.

$>$ About $86 \%$ respondents agreed to the statement that membership in SHG has increased their savings. A proportion of $56 \%$ respondents agreed to it, while approximately $1 / 3^{\text {rd }}$ respondents strongly agreed to it (Refer Table 6). Thus it can be inferred that there is a strong positive impact on savings of the members.

$>$ While studying the impact on economic independence it was found that there is strong positive impact as $80 \%$ (41\% strongly agreed, 39\% agreed) respondents were in favour of the statement (Refer Table 7). A negligible proportion of $3 \%$ respondents disagreed to this statement.

$>$ During the study it was also revealed in SHG had social impact as well apart from the economic impact. This was confirmed as $82 \%$ of the respondents said that membership in SHG has improved their standard of living (Refer Table 8). This finding is in synchronisation of the government's focus on economic development and not just on economic growth.

$>$ It was found that microfinance through SHG leads to employment generation to a very large extent as a whopping $92 \%$ of the respondents felt that membership in SHG has led to employment generation (Refer Table 9).

$>77 \%$ of the respondents were of the view that microfinance through SHG eradicates poverty (Refer Table 10)

$>$ The analysis of cross tabulation of monthly income and the impact on capacity to spend more revealed that it had a positive impact on the capacity to spend more of the members who had monthly income of less than Rs. 10,000. It didn't make much difference to the spending capacity of people earning more than Rs. 10,000 per month (Refer Table 11)

$>$ The analysis of crosstabulation of age and impact of SHG membership on value of assets (Refer Table 12) revealed that people in the age group of 25-30 years and 35-40 years were positive about it while the members of other age groups didn't feel the same.

$>$ The analysis of crosstabulation of age and impact of SHG membership on income (Refer Table 13) revealed that people in the age group of 25-30 years and 35-40 years were positive about it while the members of other age groups had a mixed response..

\subsection{SCOPE FOR FUTURE RESEARCH}

This study was undertaken only at district Fatehgarh Sahib in state of Punjab, India and the sample size of 100 respondents was small. Thus it may not be representative of the entire nation. A national level or a state level research can be carried out regarding this topic. Moreover in our study we have only studied the economic impact of microfinance through SHG. However there 


\section{INTERNATIONAL JOURNAL of RESEARCH -GRANTHAALAYAH \\ A knowledge Repository}

Management

is a scope of studying the impact of microfinance through SHG on political, social and psychological parameters as well.

\section{CONCLUSION}

It can be concluded that SHG - Microfinance is a successful step in providing access to finance to the rural needy people. The process has enabled a large number of people to engage in various income generating activities to challenge poverty. The programme, indeed, helped in improving the household conditions of the sample respondents as well as their knowledge and awareness about various issues. However, on observation the following issues were identified. The situation varies from one category of income generating activity to another category of income generating activity. As a result of income generating activities taken up by women, family incomes had substantially increased. The results from these self help groups (SHGs) are promising and it is proving to be an effective method of poverty reduction. The need of the hour is greater support from government and the banking industry so as to smoothen and speedying up the process of poverty elimination.

\section{REFERENCES}

1. Banerjee, Tanmoyee. (2009). Economic Impact of Self-Help Groups -A Case Study, Journal of Rural Development, 28 (4), 451 - 467.

2. Mohapatra, Anuja(2012)Empowerment of Women At House-Hold Level Through SelfHelp- Groups- A Study Of Khordha District of The State of Odisha, India International Journal Of Research In Commerce, Economics \& Management. 2 (5),83-87.

3. Moyle, Dollard \& Biswas. (2006).Personal and Economic empowerment in Rural Indian Women: A Self-help Group Approach. International Journal of Rural Management, 2(2), 245- 266.

4. Nirmala.K.A. and Geetha Mohan. (2009).Socio-economic impact of microcredit:A Study of Measurement. In Anil Kumar Thakur and Praveen Sharma(Ed.) Micro credit and Rural Development (pp207-224). New Delhi: Deep \& Deep Publications.

5. Pillai, Thalavai and S. Nadarajan.( 2010). Impact of Microfinance - An Empirical Study on The Attitude of SHG Leaders in Kanyakumari District-Tamil Nadu. International Journal of Enterprise and Innovation Management Studies 1( 3), 89-95

6. Rajendran.K.\& Raya.(2011)Does Microfinance Empower Rural Women? A study in Vellore District,Tamil Nadu. Indian Journal of Finance,5(11),47-55.

7. Singh., Y K., S. K. Kaushal \& S.S. Gautam (2007) Performance of women "s Self Help Groups in District Moradabad, U.P. International journal of Rural Studies, 14 (2), 1-5.

8. Subramaniam,S.(2010).Empowerment of women through SHGs in Tirunelveli District, Tamil Nadu-A SWOT analysis, Prabandhan: Indian Journal of Management,3(3),37-40.

9. Surender, Sunil Kumari, Ramesh Kumar Sehrawat(2011) Can Self - Help Groups Generate Employment Opportunity for Rural Poor? European Journal of Social Sciences. 19( 3),371-379. 